\title{
Locus-specific microsatellite markers in common bean (Phaseolus vulgaris L.): isolation and characterization
}

\author{
B. L'taief · R. Horres $\cdot$ R. Jungmann · C. Molina • \\ B. Sifi $\cdot$ M. Lachaâl $\cdot$ P. Winter $\cdot$ G. Kahl
}

Published online: 31 January 2008

(C) Springer Science+Business Media B.V. 2008

\section{Erratum to: Euphytica DOI 10.1007/s10681-007-9577-1}

Due to an unfortunate error during the production process of the above mentioned article, the figure captions of Figures 1 and 2 were interchanged. The correct representation of both Figures and captions are published on the following page and should be treated as definitive by the reader.

The online version of the original article can be found under doi:10.1007/s10681-007-9577-1.

B. L'taief · M. Lachaâl

Département de Biologie, Faculté de Sciences de Tunis,

Campus universitaire, 1060 Tunis, Tunisia

B. L'taief · B. Sifi

Laboratoire des grandes cultures, INRAT,

Rue Hédi Karray, 2080 Ariana, Tunisia

B. L'taief $\cdot$ R. Horres $(\bowtie) \cdot$ R. Jungmann $\cdot$ P. Winter

GenXPro GmbH, Frankfurt Innovation Center

Biotechnology (FIZ), Altenhöferallee 3,

60438 Frankfurt am Main, Germany

e-mail: horres@genxpro.de

B. L'taief · R. Jungmann - C. Molina - G. Kahl

Biocenter, University of Frankfurt/Main,

60439 Frankfurt am Main, Germany 


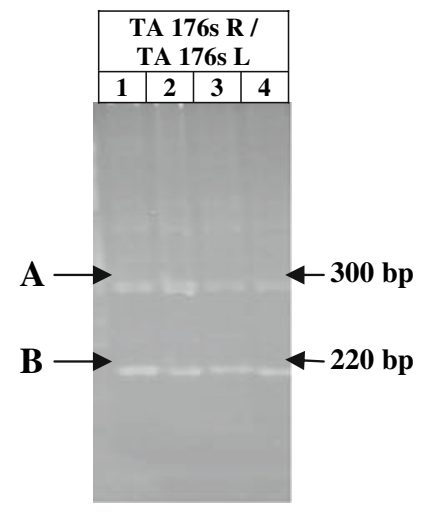

Fig. 1 Amplification of genomic DNA fragments from common bean using STMS primers TA176s derived from chickpea. Fragments A and B were isolated, sequenced, and new primers designed. Designed primers (a): generated microsatellite in Phaseolus, (b): similarities with SCOF1 and ZFP. Amplified products were separated on $10 \%$ polyacrylamide gels in $1 \times$ TBE. 1 represents BAT 477, 2 represents DOR 364, 3 represents RIL 115, 4 represents RIL147. See Table 3 for more details

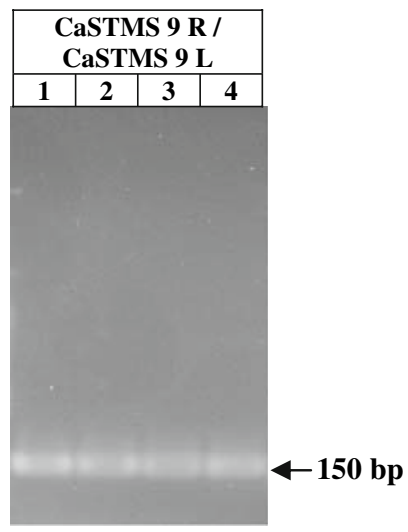

Fig. 2 Amplification of genomic DNA from common bean using STMS primers derived from chickpea. Only one fragment was amplified in each plant. Amplified products were separated on $1.8 \%$ agarose gel in $0.5 \times$ TBE. 1 represents BAT 477, 2 represents DOR 364, 3 represents RIL 115, 4 represents RIL147 